\title{
Minas dos Cataguases* \\ Entradas e Bandeiras nos sertões do Eldorado
}

\author{
The Cataguases' Minas \\ Colonial expeditions in the El Dorado Backlands
}

\author{
MARIA LEÔNIA CHAVES DE RESENDE \\ Doutora em História Social da Cultura/UNICAMP. \\ Professora e Coordenadora do curso de pós-graduação em História de \\ Minas Gerais, XVIII - XIX / DECIS/Universidade Federal de São João del-Rei
}

RESUMO Este artigo trata da política indigenista de Minas Gerais, instituída pelo governo, ao longo da segunda metade do século XVIII, e a contrapartida indígena à apropriação de suas terra, por meio de concessão de sesmarias aos colonos participantes das entradas e bandeiras.

Palavras-chave Etnohistória indígena, entrada e bandeiras, Minas Gerais colonial

ABSTRACT This articles deals on the resistance of the Brazilian Indians, stalked into the wilderness by explorers, expelled from their lands in Minas Gerais in the eighteenth century.

Key words Native Ethnohistory, colonial expeditions, Minas Gerais history

Artigo recebido em: 25/08/2004 - Aprovado em: 15/12/2004. 


\section{1 -}

Os trabalhos sobre a Minas dos Cataguases, prenúncio de uma história batizada sob os auspícios de populações indígenas, pouco contribuíram para o conhecimento do processo a que esses povos foram submetidos durante o século XVII. Mesmo que a presença desses indígenas tenha sido, reiteradas vezes, tema das discussões administrativas e eclesiásticas, para a historiografia mineira, eles são completos desconhecidos. ${ }^{1}$ Ainda que uns poucos reconheçam a participação dos índios, antecipam suas ressalvas ao reduzirem tal atuação aos primeiros contatos, sem os tomar sequer como agentes históricos na formação sócio-cultural de Minas. E mesmo quando reconhecidos, foram reputados como meros apêndices dos estudos, se prestando quase sempre a um papel secundário à ação colonizadora. ${ }^{2}$ Objeto de raríssimas pesquisas, a Etnohistória indígena mineira colonial deixou, por isso, esparsas contribuições, acabando por impor um silêncio avassalador, apesar de uma vasta e rica documentação dispersa pelos seus arquivos. ${ }^{3} \mathrm{O}$ que se percebe, portanto, é uma desproporção entre a riqueza qualitativa e quantitativa das fontes coloniais e o volume da produção sobre a história indígena na Minas colonial.

Uma das principais justificativas, alegadas como pretexto por parte da historiografia, foi o genocídio encetado pelas entradas e bandeiras no final do séc. XVII e início do séc. XVIII. Nessa vertente explicativa, os colonos, penetrando os sertões, avançaram indiscriminadamente sobre territórios indígenas, dizimando toda a população nativa. ${ }^{4}$ Chacinados pela violência das expedições, os índios teriam, dessa forma, desaparecido da história. De fato, Nelson de Senna, referência obrigatória nos parcos estudos sobre a questão indígena mineira, é um exemplo notável dessa visão que acabou por deitar raízes. Afirmava que, após as entradas dos bandeirantes, ao final do século XVII, o gentio sofrera uma "guerra porfiada e constante até que foi na maior parte exterminado, emigrando outra grande porção para Goiás e Mato Grosso, enquanto que um reduzidíssimo número de tribos permaneceu nos vales mais cobertos de matas virgens e em recantos mais afastados do nosso território, fora de maior contato com a população civilizada já então existente nas Minas". Quan-

1 Para uma reflexão sobre esse "vazio" existente na historiografia mineira ver o elucidativo e pioneiro artigo de VILAS BÔAS, Crisoston Terto. A questão indígena em Minas Gerais: um balanço das fontes e bibliografia. Revista de História. Ouro Preto, LPH. n. 5, 1995. p. 42-55.

2 O levantamento bibliográfico sobre a história indígena em Minas Gerais, realizado por mim e por Isabel Missagia de Mattos, deixa evidente que muitos trabalhos somente apontam a participação dos indígenas por ocasião da "fundação" das cidades. Bibliografia sobre História Indígena em Minas Gerais.(manuscrito).

3 Ver o rol de fontes sobre a História Indígena Colonial em RESENDE, Maria Leônia Chaves de. Gentios Brasílicos: índios coloniais na Minas Gerais Setecentista. Campinas: UNICAMP, 2002 (tese de doutorado).

4 Harold Langfur vê nessa alegação a explicação dada como pretexto para justificar a omissão dos historiadores na questão indígena em Minas Gerais. LANGFUR, Harold. The Forbidden Lands: Frontier Settlers, Slaves, and Indians in Minas Gerais, Brazil, 1760-1830. Austin, Faculty of the Graduate School, University of Texas, 1999, p 22. 
to aos "índios mansos", que formavam o grosso das bandeiras paulistas, "não se fixaram na terra de Minas". Assim, conclui, que "sob o ponto de vista da formação da gente mineira, o índio apenas teve aquele momento histórico de penetração e conquista do solo das Minas". ${ }^{5}$ O mais significativo nessa interpretação é que, considerados exterminados pelas investidas devastadoras dos colonos, os índios não teriam participado da construção da vida mineira, sendo dela excluídos.

Nosso objetivo, neste artigo, é demonstrar que muito distante dessa idéia, boa parte da história de Minas esteve imbricada na questão indígena. Um indicador indiscutível foi a política indigenista encetada pelos governadores da capitania, cuja maior expressão foram as entradas e bandeiras que exploraram território indígena ao longo de todo o século $\mathrm{XVIII.}{ }^{6}$ Ao longo de todo o setecentos, as entradas nos sertões, chamadas por sinonímia de "áreas proibidas", foram o zênite dos homens de Minas Gerais - e a desventura dos povos indígenas. Portanto, muito diferente do que se faz crer, essas campanhas não se extinguiram logo nos primeiros anos, mas perseveraram por todo o período colonial, culminando no desfecho da guerra contra os Botocudos de 1808. ${ }^{7}$

\section{II -}

Mesmo que a valorização dos descobrimentos estivesse associada à extração de metais preciosos e, por extensão, às benesses de cargos e funções, não se pode subestimar que a prática de escravização indígena e a conquista de terras, com o controle sobre passagens e rotas comerciais, fossem uma das alavancas que despertou o interesse para muitas das bandeiras. Assim, por todo o período colonial, as entradas para os sertões de Minas foram movidas por este tripé de interesses: a terra (que era concedida como sesmaria àquele que dela se apossasse), a busca do ouro e das pedras raras (que estimulava os mais ávidos pela riqueza) e a preagem dos índios (que, a mais das vezes, se prestava como reduto de mãode-obra para a lavra mineral ou agrícola e, sobretudo, como escravos domésticos, vivendo sob a administração dos colonos).

Para dar conta desses intentos, inúmeras expedições foram organizadas para adentrar os sertões, cunhando várias designações: bandeiras, entradas, conquistas, descobrimentos, jornadas, partidas, companhias ou campanhas - todos termos que foram tomados uns pelos ou-

5 SENNA, Nelson de. A terra mineira. Corografia do Estado de Minas Gerais. Belo Horizonte: Imprensa Oficial. 1926, p. 47,49

6 Ver Apêndice I - Entradas e Bandeiras em Minas Gerais, século XVIII. RESENDE, Maria Leônia Chaves de, op. cit. p. 379-383.

7 John Monteiro considera que, com o êxodo dos paulistas para as minas, houve a suspensão das atividades de apresamento. MONTEIRO, John M. Negros da Terra. Índios e Bandeirantes nas Origens de São Paulo. São Paulo: Companhia das Letras, 1994, p. 210. 
tros na Minas do século XVIII. Com muita propriedade, Francisco de Andrade lembra que o caráter público/estatal versus privado/particular das expedições nem sempre procede, já que se deve dar atenção "às práticas e funções distintas que iam sendo enfeixadas sob o mesmo nome, conforme as circunstâncias". Daí, a bandeira e seus termos correlatos poderiam ser compostos de variadas formas e funções. ${ }^{8}$

A prática mais comum era obter a concessão, na forma de patente, para montar a bandeira. Muitos que ousavam fazer entrada sem a permissão oficial eram presos sem delonga. ${ }^{9}$ Afinal, as conquistas significavam ganhos territoriais da Coroa e implicavam a expansão de seus domínios - e, em consonância com as políticas e interesses dos capitães generais, contaram com recursos e anuência do Estado. Para os afortunados, concedia-se uma sesmaria como mercê - que funcionava como benesse e estímulo.

O interesse dos colonos pela terra não era gratuito por motivos um tanto óbvios. Vários estudos têm demonstrado o quanto os negócios com a terra foram lucrativos ao lado da extração mineral e da exploração do trabalho escravo no Brasil colonial. ${ }^{10}$ Seguramente, em Minas, o acesso a possessões territoriais, por meio das conquistas, foi a força propulsora da riqueza de vários colonos. Os inventários de administradores de índios e entrantes nos sertões de Minas - atribuições que, a mais das vezes, se confundiram - dão indicações seguras do quanto o processo de formação de seus bens esteve atrelado à questão territorial. A maioria deles constituiu sua riqueza pelo patrimônio fundiário, sendo sua aquisição por meio da concessão de sesmarias em territórios ocupados pelas populações indígenas, sobretudo com a expansão para o interior mineiro. ${ }^{11}$ Por isso mesmo, aos participantes das bandeiras era assegurado o quinhão de datas minerais e sesmarias. ${ }^{12}$

Conforme determinação de 1731, do Conselho Ultramarino, cabia meia légua de quadra de terra ao que primeiro rogasse a ocupação da terra, sob a condição de possuir escravaria o bastante para cultivar as roças. Para tanto só poderia ser reivindicada em sesmaria uma posses-

8 ANDRADE, Francisco Eduardo de. A invenção das Minas: empresas, descobrimentos e entradas nos sertões do ouro (1680-1822). 2002. Tese (Doutorado) - Departamento de História, USP, São Paulo. 2002, p. 150.

9 Foi o que aconteceu a Tomás de Aquino, que fez uma picada em direção ao Campo dos Goitacases, em 1782. Foi preso por não terem os papéis com o despacho do governador autorizando a entrada. APM, CC525, planilha 20110.

10 Sheila Faria revê sua posição em trabalhos anteriores que difundia a noção de "terras livres" no Brasil escravista. Para a autora, não é possível deixar de reconhecer os embates com as populações indígenas que barraram a expansão ilimitada do europeu. FARIA, Sheila, Colônia em movimento..., p. 122. Analisando o processo de formação da hierarquia social do Rio de Janeiro, Fragoso demonstrou que a economia colonial marcada pela pouca liquidez, estava assentada em mecanismos de reprodução cujos pilares eram a trabaIho, terra e crédito. FRAGOSO, João Luís. A espera das frotas: hierarquia social e formas de acumulação no Rio de Janeiro (XVII) . Cadernos n.1, Rio de Janeiro, LIPHIS /UFRJ, 1995. p. 53-62.

11 Ver em RESENDE, Maria Leônia Chaves de, op. cit., p. 98-103, em que localizamos inventários e testamentos de alguns dos entrantes para compor o universo social e econômico daqueles homens.

12 APM (Arquivo Público Mineiro), SC186, fot.1011-1013. 
são de terra devoluta, ouvidas as Câmaras, e devidamente confirmada em "carta", pelo crivo real ou seus plenipotenciários. ${ }^{13}$

Por determinação do Estado, estabeleceram-se os limites para os aldeamentos. Apesar disso, na prática, poucas vezes o respeito às terras indígenas foi observado, já que a política de se conceder possessões onde houvesse aldeias indígenas foi recorrente. O fato é que apenas do ponto de vista estritamente formal, reconhecia-se os direitos dos índios sobre suas terras. Na prática, o que ocorreu foi a invasão reiterada de terras indígenas.

Eram os próprios colonos que se incumbiam de recorrer a muitas artimanhas para burlar as restrições legais. Em geral, o conquistador somente requeria a carta de sesmaria anos depois da conquista, quando então alegava não haver prejuízo aos índios - naturalmente depois de proceder a sua expulsão. Além do mais, difícil era controlar em que medida as terras eram ocupadas efetivamente por populações nativas. Muitas vezes, o sesmeiro omitia tal informação, para ganhar tempo e reprimir os "invasores".

Desde o início da colonização, vários entrantes admitiam ter se apossado de terras das aldeias. Em 1723, por exemplo, D. Izabel Maria Guedes de Britto solicitava a ratificação da provisão que Ihe assegurava uma sesmaria "para que não fosse inquieta na sua posse". Tais terras, nas vertentes do rio das Velhas, explicava, foram "descobertas, povoadas e conquistadas ao gentio à custa da fazenda do seu pai na boa fé de the pertencerem" e, por isso, durante "muitos anos as defendeu". ${ }^{14}$ De fato essa prática foi recorrente e atravessou todo o setecentos. No final do século, outros ainda usavam o mesmo pretexto como foi o caso de Miguel Antônio Vieira e Bernadino José da Silva, moradores na freguesia de Guarapiranga. Alegavam que seus pais "conquistaram a dita paragem então habitada pelos índios" e nela "puseram posse". ${ }^{15}$

Quando e se notificadas, nem sempre as autoridades agiam em conformidade com a lei, ao relevarem o direito dos índios. E, mesmo quando se fazia respeitar a pena da lei, os limites territoriais impostos ao aldeamento eram, quase sempre, insuficientes para sua manutenção. Não faltaram medidas administrativas em que se tomou por terra devoluta toda a mata ao redor dos aldeamentos, excluindo, portanto, a área de caça e de coleta de plantas. Ao agir dessa forma, circunscreviam a possibilidade de sobrevivência da aldeia, limitada na reprodução do seu modo de vida.

\footnotetext{
13 APM , SC 224, fot. 2068-2074. A unidade de área utilizada era a légua em quadra ou légua quadrada. A légua de sesmaria equivale a 6,6 quilômetros, e a légua em quadra, portanto, a 43,56 quilômetros quadrados ou 4.356 hectares. Sobre a legislação que vigorou nas concessões de sesmarias, ver BARBOSA, Waldemar. História de Minas. Belo Horizonte: Ed. Comunicação, 1979, p. 231-251

14 APM, SC23, rolo 5, fol. 20, 20V.

15 APM, CC547, planilha 21585.
}

190 VARIA HISTORIA, $n^{\circ} 33$ 
O próprio governador admitia fazer as concessões de sesmaria, sem respeitar o disposto na lei, já que o objetivo principal era povoar com brevidade as conquistas. A serem respeitadas as exigências, comentava o governador, "seriam necessário anos para se proceder a informações, justificações, respostas de ministros e mil embaraços que eternizarão a conclusão de qualquer negócio". ${ }^{16}$ Não demorou para que, distorcendo a realidade, o discurso colonial passasse a tratar os índios como os invasores das terras tituladas em sesmarias, justificando, assim, todo o aparato repressivo contra as populações indígenas. Esse espírito foi fundamental para promover o processo de conquista e ocupação dos territórios, favorecendo, em Minas, a concessão de 7.991 cartas de sesmaria entre 1701 e $1836 .{ }^{17}$

\section{III -}

Não é novidade alguma as inúmeras ordens expedidas em Minas, proibindo a atuação das ordens religiosas, acusadas de, sob o pretexto da prática da catequese, se prestarem ao contrabando e extravio de riquezas minerais. Se em muito se carregou nas tintas ao tratar essa legislação como algo atípico ou especial — como considerou Caio Boschi - , certo é que a ausência de ordens regulares (ao menos formalmente) imprimiu uma especificidade para a questão indígena em Minas. ${ }^{18}$

A impossibilidade da autoridade colonial de controlar o extravio do ouro fez com que o Estado mantivesse intencionalmente populações indígenas afastadas do contato - como um cinturão de resistência nos sertões, intimidando a penetração dos contrabandistas, ávidos em explorar as jazidas minerais à revelia do interesse metropolitano. Por isso mesmo, durante a primeira metade do século XVIII, o governo da capitania não se incumbiu da "civilização" dos índios, que, muitas vezes, prestavam melhores serviços intimidando os colonos na penetração no interior. No entanto, o cenário econômico agravara-se na segunda metade do século e à reboque da crise uma nova estratégia na política indigenista se configurou para atender às necessidades da capitania.

De fato, o quadro econômico e social de Minas apresentava-se como

16 APM, SC224, fot. 2068-2069.

17 MORAES, Leonardo Pires de. O índio na história de Minas Gerais. O século XVIII. Belo Horizonte: UFMG, 1992 (Relatório Final de Iniciação Científica), p. 40. Waldemar Barbosa contabilizou, de 1710-1822, o total de 6.364 sesmarias. Waldemar Barbosa, op. cit., p. 244. No índice geral das RAPM [1896-1913], há uma listagem nominal das sesmarias concedidas de 1710 a 1835

18 Sobre essas ordens, ver BN (Biblioteca Nacional), SM, cód. 1, 2, 6, título 7, "Religiosos, clérigos e matérias eclesiásticas". Sabe-se, contudo, que a revelia das determinações, alguns frades recalcitrantes permaneceram na Minas. Sobre o caráter do clero mineiro, ver BOSCHI, Caio César, Os leigos e o poder. Irmandades leigas e política colonizadora em Minas Gerais. São Paulo: Ática, 1986, p. 79-86. Sobre a crítica a essa visão, ver FERREIRA Renata Resende Silva. Entre a ambição e a salvação das almas: a atuação das ordens religiosas em Minas Gerais (1698-1759). Anais Eletrônicos do XIV Encontro Regional de História. UFJF, 24 a 30 de julho de 2004. 
fonte de apreensões e diligências. "A capitania geme oprimida da necessidade por falta de descoberto", lamentava um colono. ${ }^{19} \mathrm{~A}$ administração evidenciava bem isso, externando suas preocupações com a queda da arrecadação dos quintos reais. Se a questão econômica era a tônica, foi seguramente a ocupação de territórios férteis e promissores pelas populações indígenas que ameaçava real ou imaginariamente as bases da colonização, o que se transformou na justificativa oportuna para a situação de penúria de Minas. Sem sinais de trégua, aqueles "inimigos" continuavam aterrorizando governadores, autoridades e colonos. ${ }^{20}$ Segundo Laura de Mello e Souza, o gentio bravo, o quilombola e o vadio encarnavam esta imagem no imaginário político da época, tornando-se uma obstinação para administração pública. ${ }^{21}$ Não sem razão, combinando discursos sobre formas de controle e tentativas de desenvolvimento para Minas, deparamo-nos, neste contexto, com inúmeras referências aos índios como barreira natural a esse projeto.

Data desse mesmo período, como lembra Moraes, uma transformação na representação que até então se fazia dos índios. Até meados do século XVIII, na ótica dos colonos, os índios eram vistos como ingênuos, fracos, carentes de auxílio. A partir do momento em que a política dos governadores passa a ser mais agressiva, com a ocupação de territórios indígenas, a imagem que deles se produziu acompanhou os novos interesses governamentais. Reinventou-se o tema da antropofagia, como característica inerente dos índios e, portanto, justificativa para sua conquista. ${ }^{22}$ Percebendo tal estratagema, definiu-se uma tipologia nas frentes avançadas de povoamento da região do rio Doce, na década de 70: índios mansos, domésticos, aldeados nos presídios e dispostos à conversão; índios pacíficos, mas traidores, desde que o contato com o branco não satisfaça mais suas expectativas; e belicosos antropófagos, vistos como inimigos irredutíveis. ${ }^{23}$

Acompanhando esse espírito, documentos da época mudaram, decisivamente, o tom ao tratar do indígena. Carregaram tintas de horror sobre a índole dos indígenas, que passam, então, a serem vistos como perigosos, maliciosos, traidores e dados a práticas canibais. Dotados

19 PR (Projeto Resgate), AHU (Arquivo Histórico Ultramarino), 10776, cx. 145 doc.5.

20 De Mariana, seguiu uma representação para que se ouvisse "benignamente as súplicas e favorecer a indústria e comércio com as providências que parecem justas, atendendo a defesa natural dos nossos colonos fronteiros ao sertão, com presídios municionados de caçadores e soldados indianos que são mais prontos para prevenir as hostilidades dos Puris e Botocudos, como se praticava nos governos antecedentes, na certeza de terem baixados os dízimos do termo desta cidade a vinte e sete contos de réis, com a deserção das fazendas mencionadas e prejuízo mineral, podendo, aliás, o mesmo termo pela sua extensão produzir mais de quarenta contos de dízimos". PR, AHU, 11722, cx. 160, doc. 82.

21 SOUZA, Laura de Mello e, Norma e conflito. Aspectos da História de Minas no século XVIII. Belo Horizonte: Ed. UFMG, 1999., p. 91.

22 MORAES, Leonardo Pires de. O índio na História de Minas Gerais. O século XVIII. Belo Horizonte: UFMG, 1992. (Relatório Final de Iniciação Científica).

23 SOUZA, Laura de Mello e, op. cit., p. 91. 
dos mais sórdidos atributos, os índios foram tomados em baixa conta. Ferozes, bárbaros, selvagens, indolentes — foi esse o coro que ecoou no vozerio dos homens letrados ao mais ordinário colono que fez dos índios o enxurro da Minas colonial.

Esse discurso repercutiria decisivamente na "política indigenista" implementada em todo o período colonial. A partir da década de 60, em função da crise que se abateu sobre Minas, a alternativa dos governadores foi avançar os sertões, referida nos mapas da época como "terras incógnitas ou proibidas". ${ }^{24}$ Desde então, as entradas passam a ser cada vez mais uma atribuição direta do governo que, cioso de tal papel, passou a delegar aos seus agentes diretos a incumbência de devassar o território. ${ }^{25}$

É nesse contexto que a Lei da Liberdade (1755) e do Diretório (1758) foram postas em prática em Minas. Na ocasião de sua aplicação no Brasil afora, foi Silva Lobo, então governador de Pernambuco, quem foi incumbido de supervisionar sua execução. ${ }^{26}$ Seria ele próprio quem, cinco anos depois, assumiria o posto de governador de Minas Gerais, em 1763, adaptando essa legislação à realidade mineira. Em um registro no livro de sua secretaria de governo, esboçou a base de suas ações - nem um pouco atentas a colocar em prática a determinação inequívoca de assegurar a liberdade dos índios. ${ }^{27}$ Para legitimar sua ação, Silva Lobo recorreu a um expediente bastante sagaz. Tirando proveito da contradição da lei, o governador subverteu sua lógica. Isso porque embora a lei determinasse a liberdade incondicional para os índios aldeados, em Minas, os indígenas ainda não tinham sido reduzidos aos aldeamentos por ocasião de sua promulgação. Silva Lobo ordenou, em total desrespeito ao princípio da lei, que primeiro se procedesse à redução dos índios nos aldeamentos - "violentamente se necessário"-, submetendo os indígenas ao que seus contemporâneos, usualmente, chamaram de "conquista". O precedente legal — a Lei de Liberdade de 1755 — que determinava que as autoridades salvaguardassem aos índios a "liberdade das suas pessoas, posses e comércio" — direito que não podia ser "suspenso ou usurpado debaixo de qualquer título ou pretexto" — foi, assim, "reinterpretado" para os indígenas de Minas. Em desafio explícito ao ditame da Lei de 1755, ele ordenou as tropas da capitania para oporem força militar à resistência indígena. Embora invocando ordens reais, Silva Lobo revelou sua vontade de agir em detrimento da intenção declarada da Coroa e também em exceder o alcance das instruções diretas de

24 LANGFUR, Harold, op. cit., p.72.

25 LANGFUR, Harold. op, cit., p.19-20; 72-119.

26 Lobo e Silva foi incumbido de "ampliar o benefício do Breve de Benedito XIV e das Leis de 6 e 7 de junho de 1755" - que concedeu a liberdade aos índios do Maranhão - para "todos os que habitam o continente do Brasil". APM, CC156, rolo 148, p. 1.

27 Sigo aqui a brilhante análise feita por Harold Langfur, especialmente no capítulo 2. 
Furtado de Mendonça. A liberdade dos índios, ele deixou claro, não seria interpretada como a liberdade para manter sua vida tradicional, nômade, mas simplesmente o direito - ou mais precisamente, a obrigação de contribuir para a sociedade colonial como vassalos cristãos, leais, sedentários e industriosos. E para garantir seu intento deflagrou a conquista como política a ser adotada.

Com esse espírito, Silva Lobo encarnou o confronto militar contra as populações indígenas, alavancando a formação de outras tantas bandeiras na segunda metade do século XVIII para se proceder à conquista dos sertões e do gentio. Coincidência ou não, os anos 60 foram o período em que mais se concedeu sesmarias: entre 1764 e 1768, o governador Luís Diogo Lobo da Silva concedeu 362, que correspondeu a uma média anual de 90,5; José Luís de Meneses, seu sucessor, entre 1768 e 1773, concedeu 443, perfazendo uma média de 88,6 a cada ano. ${ }^{28}$ Afinal, a chave para salvar a capitania de seu declínio foi, então, focalizar as terras ainda sob controle dos índios. Seguindo essa lógica, durante toda a segunda metade do século, as entradas aumentaram, como se pode ver no quadro abaixo:

\section{Quadro I - Entradas - (1710-1808) ${ }^{29}$}

\begin{tabular}{cc}
\hline Ano & Número de Entradas \\
\hline $1710-1720$ & 4 \\
\hline $1720-1730$ & 4 \\
\hline $1730-1740$ & 7 \\
\hline $1740-1750$ & 2 \\
\hline $1750-1760$ & 3 \\
\hline $1760-1770$ & 26 \\
\hline $1770-1780$ & 20 \\
\hline $1780-1790$ & 17 \\
\hline $1790-1800$ & 4 \\
\hline $1800-1808$ & 6 \\
\hline Total & 93 \\
\hline
\end{tabular}

Fontes: Apêndice I - Quadro das Entradas e bandeiras, Minas Gerais, século XVIII (RESENDE, Maria Leônia Chaves de. Gentios Brasílicos: índios coloniais na Minas Gerais Setecentista. UNICAMP, 2002 (tese de doutorado)

28 Id. ibidem, p. 114. BARBOSA, Waldemar, op. cit., p. 243, 244

29 Esses números são números relativos, pois não consideramos aqui as entradas não-oficiais do início do século e o maior controle administrativo-político-militar que se instalou na capitania, na segunda metade do século XVIII, aumentando significativamente as expedições. Não consideramos também as entradas de 1808 , durante a Guerra contra os Botocudos. Incorporei, nesse quadro, as preciosas indicações que me foram gentilmente cedidas por Harold Langfur. 
Uma das entradas mais impressionantes - e das mais violentas foi a do Cuité, em 1765. Silva Lobo mandou chamar Antônio Pereira e Antônio Cardoso de Souza, "pela boa informação por serem muito práticos dos sertões e matos habitados pelo gentio que punha em desassossego as fazendas" - e fez levantar bandeira no distrito do Cuieté, "para evadirem (...) e domesticarem o gentio". ${ }^{30}$ Sob os auspícios do governo, montou a expedição - se não foi uma das maiores, seguramente uma das mais bem documentadas campanhas para percorrer toda a região ribeirinha dos rios Doce, Sacramento, Santa Rita, São Bartolomeu, Sem Peixe, do Peixe e Guarapiranga, além da freguesia da Barra. Para financiar seu empreendimento, o governador estabeleceu uma "contribuição voluntária", "feita segundo as possibilidades de cada qual" — mas, na verdade, uma cobrança compulsória sobre a população "hostilizada do gentio silvestre". Atenuando as possíveis críticas e justificando o benefício aos próprios colonos, conclamava a todos para a "conservação de suas fazendas". Afinal, prosseguia com seu argumento, os recursos seriam usados para "embaraçar o corso com que o gentio silvestre de nação Botocuda que faz despovoar o descoberto do Cuité" onde todos os anos entravam "pelas fazendas e sesmarias (...), cometendo hostilidades de mortes, destruição de gado e plantas das referidas fazendas". Para dar cabo de seu plano, procedeu a uma verdadeira arrecadação. Só no termo de Mariana, taxou 149 pessoas a duas oitavas.

Do confronto, pouco se teve notícia, sucintas que foram as descrições dos embates. Coube, contudo, ao capitão listar o armamento de que dispunham: cerca de 74 arrobas de chumbo, 9 arrobas de pólvora e 520 perdeneiras de fogo, 108 facas de cabo de peso e 150 machadinhas e foices pequenas. Os medicamentos das boticas disseram bastante do quanto foi preciso para aliviar a penúria dos colonos em combate: 5 libras de papoulas, antimônio, azeite doce, água ardente do reino e tártaro emético - todas substâncias de que lançavam mão os cirurgiões. ${ }^{31}$ Para ministrar as missas e os funerais, 2 frascos de vinho, uma libra de farinha para hóstias, uma folha de flandres e uma folhinha de reza. E para o ânimo dos sobreviventes, não faltou um barril de cachaça.

Para total desapontamento dos sertanistas, a empreitada selou uma derrota vexante. Pouco tempo depois, os moradores de Antônio Dias reconheciam, em uma petição, que, apesar do empenho, encontravam-

30 APM, CC1156, rolo 148, p.1-45. Sigo, a partir daqui, as informações, neste documento, para dar as descrições desta expedição.

31 Sobre essa questão, ver MARQUES, Vera Regina Beltrão. Natureza em boiões. Medicinas e boticários no Brasil setecentista. Campinas: Ed.. Unicamp, 1999. MARQUES, Vera Regina Beltrão "Medicinas secretas magias e ciência no Brasil setecentista, In: CHALHOUB, Sidney et all (org.) Artes e ofícios de curar no Brasil. Campinas: Edit. Unicamp, 2003. FIGUEIREDO, Betânia Gonçalves. A arte e curar: cirurgiões, médicos, boticários e curandeiros no século XIX em Minas Gerais. Rio de Janeiro: Vício de Leitura, 2002. 
se receosos, abatidos e extenuados com os freqüentes assaltos dos Botocudos no Cuieté. Para contornar tal malogro, no ano seguinte, em 1766, um ano e pouco depois do fracasso da primeira expedição, 151 moradores de São Miguel foram novamente tributados, para armar uma nova expedição, "em socorro da segunda conduta para a conquista do Cuieté". Diversas localidades apoiaram a nova empreitada: de Antônio Pereira, Aiuruoca, Barra, Camargos, Catas Altas, Furquim, Inficionado, Mariana, Morro de Gaspar Soares, Pitangui, Rio Pardo, São Caetano, São Sebastião, São João del-Rei, São José del-Rei, Sumidouro, Vila do Príncipe. ${ }^{32}$

Os resultados deste segundo confronto tampouco foram descritos, constando apenas notas esparsas na documentação. Sabemos, contudo, do total desapontamento do governador Silva Lobo com o capitão Antônio Cardoso. João da Silva Pereira de Souza, alcagüete a mando do governador, respondeu prontamente sua ordem de dar "informe da bandeira do capitão Antônio Cardoso de Souza", a quem devia "pôr os olhos com toda a miudeza" por ser ele "indigno da ocupação de bandeirista". A bem da verdade, o capitão Antônio Cardoso era acusado de "suborno", apropriando-se de cotas de ouro, e de "induzir os índios". ${ }^{33}$ Com essa notícia, fica evidente que as tentativas de controle das instâncias do governo não eram suficientes para aplacar a índole indomável daqueles homens que, desafiados com a lida nos sertões, muitas vezes, trataram de garantir a fidelidade aos seus próprios interesses. ${ }^{34}$

À medida que avançava o século XVIII, estendiam-se as conquistas territoriais sobre territórios tradicionalmente indígenas. Uma das regiões mais afetadas foi certamente a Zona da Mata. ${ }^{35} \mathrm{~A}$ primeira área ocupada foi a região do norte - o chamado sertão do Cuieté, então ocupado pelos índios Botocudos. Essa região correspondia aos vales da margem direita do rio Doce, até Ponte Nova e Manhuaçu, pela sua proximidade com as freguesias mais orientais do termo de Mariana: Furquim e Barra Longa. A segunda região - a central da Mata - localizada no vale do rio Pomba, o "núcleo de maior concentração indígena", seguiu essa mesma tendência.

32 APM, CC1156, rolo 148

33 BN, SM, cód. 18, 2, 6, p. 1188. O recurso de espiões parece ter sido expediente comum. Pamplona enviou um Simão Roiz, para seguir e vigiar as bandeiras de José Serra Caldeira e Antônio Cardoso. ABN, SM, cód. 18, $2,6$.

34 Refiro-me aos interesses privados de alguns entrantes à despeito dos metropolitanos. Ver, por exemplo, as reclamações contra Inácio Correia Pamplona por dividir sesmarias já concedidas pelo governador Luiz Diogo. BN, cód. 18,2,3 - Livro de Correspondências. S.I., s/d, Livro Cívico de Cartas de Coronéis e Sargentos mores, doc. 1

35 Em um estudo pioneiro, Ângelo Carrara, recorrendo a títulos de escrituras e inventários, mapeou a ocupação territorial da região da Mata. Chamou a atenção para a distinção entre as regiões da zona da Mata de Minas Gerais, distinguindo três sub-regiões: norte, central e sul. CARRARA, Ângelo Alves. Estruturas Agrárias e Capitalismo: contribuição para o estudo da ocupação do solo e da transformação do trabalho na zona da Mata mineira (séculos XVIII e XIX). Mariana: UFOP/ Departamento de História, Núcleo de História Econômica e Demográfica. Série Estudos 2, 1999. p. 15. 
Em 1770, o Conde de Valadares dava ordem expressa para que não se demarcasse sesmarias na região. ${ }^{36}$ À revelia de seu intento, em 1783 já se achavam ocupados os vales dos rios Pomba - até a foz do rio Formoso, especialmente desde as cabeceiras de seus afluentes ribeirão de Santo Antônio e rio Turvo Limpo. ${ }^{37}$ Nas duas décadas seguintes todo o vale do rio Xopotó Novo até sua barra no rio Pomba foi sendo ocupado, o que, então, se constituía no território da freguesia de São João Batista do Presídio. ${ }^{38}$ Aplicava-se assim para a região da Mata o que Inácio Correia Pamplona empregava no Triângulo Mineiro durante aqueles mesmos anos.

As entradas significaram franca hostilidade contra as populações indígenas, já que, a ocupação de seus territórios tradicionais levou à expulsão e ao desalojamento de suas terras. No entanto, essa ocupação não foi sem resistência, implicando diversos confrontos:

Confrontos violentos nos sertões, $1760-1808^{a}$

\begin{tabular}{cc}
\hline Ano & Número \\
\hline $1760-64$ & 3 \\
\hline $1765-69$ & 42 \\
\hline $1770-74$ & 1 \\
\hline $1775-79$ & 12 \\
\hline $1780-84$ & 4 \\
\hline $1785-89$ & 0 \\
\hline $1790-94$ & 7 \\
\hline $1795-99$ & 1 \\
\hline $1800-04$ & 11 \\
\hline $1805-08^{a}$ & 4 \\
\hline Total & 85 \\
\hline
\end{tabular}

Fontes: LANGFUR, Harold. Sources of Conflict: The Evidence of Indian Resistance in Eastern Minas Gerais, 1760-1808. Latin American Studies Association Conference Washington, D.C., September 6-8, 2001. APM, CC, cód. 1156; APM, SC, códs. 118, 224, 260, 277; BNRJ, SM, II-36,5,32; cód. 2,2,24, cód. 19,3,39, cód. 3,1,35; BNRJ, SM, CV, cód. 18,2,6; RAPM 1:4 (1896): 781; VASCONCELOS, Diogo P. R. de, Breve descrição, 147-8; VASCONCELOS, Diogo [Luís de A. P.] de, História média de Minas Gerais, 4 ed. (Belo Horizonte: Itatiaia, 1974), 203; CAMBRAIA e MENDES, "Colonização," 142.

a Excluídos os incidentes depois de 13 de Maio de 1808, com a declaração da guerra contra os botocudos.

36 APM, SC164, fot. 1162-1164.

37 Respectivamente nos municípios de Mercês, Aracitaba, Paiva, Silveirânia, Dores do Turvo, Senador Firmino, Divinésia, Paula Cândido e Viçosa.

38 Correspondente aos atuais municípios de São Geraldo, Guiricema, Visconde do Rio Branco, Ubá, Rodeiro e Guidoval. CARRARA, Ângelo, op. cit., p. 34. 
De fato, não era qualquer coincidência que, a partir dos anos 60, quando as terras indígenas passaram a ser ocupadas pelas frentes de expansão colonial, os embates com as hordas do gentio tenham aumentado significativamente. Não faltaram queixas dos sesmeiros que tiveram suas terras novamente invadidas. Os ataques indígenas prejudicavam os posseiros nos sertões do Abre Campo, Casca e Arrepiados, que "não podiam cultivar as terras por causa das agressões dos gentios". ${ }^{39}$

Incontáveis são os registros desses embates que traziam grandes danos para os colonos e para o governo. ${ }^{40}$ Encabeçando a tropa de combate ao gentio, no destacamento de Santana dos Ferros no Rio Santo Antônio, o cel. Damasceno do Reis relatava que, por causa dos "insultos do gentio bárbaro Botocudo", muitos moradores tinham abandonado suas fazendas "em público prejuízo do Real Erário". ${ }^{41}$ Da região do termo de Sabará, computavam-se 50 fazendas abandonadas por causa das "invasões dos índios bárbaros". ${ }^{42} \mathrm{Em} 1787$, o sargentomor Pedro Alfonso Galvão de São Martinho, de Barra Longa, informava a respeito da necessidade de gente para guarnição no destacamento de Arrepiados. Relatava os assaltos na região, por causa do "bárbaro gentio", provocando a fuga dos moradores. Vinte e cinco fazendeiros deixaram-se vencer e renunciaram as suas terras com o temor dos Botocudos e Puris. ${ }^{43}$ Fica patente, portanto, que mais que um ataque frontal, os índios estavam de fato respondendo à ocupação de suas terras, com a anuência do governo.

Se não bastasse a simples usurpação do território, os colonos recorreram ao expediente de alegar a compra das glebas de terra destinadas aos aldeamentos, apesar das disposições legais em contrário que proibiam negociações dessa natureza. Em 1784, na conquista de Arrepiados, região de Ponte Nova, João de Souza Passos, morador em Ponte Nova, interpôs um recurso no senado da Câmara de Mariana, alegando que havia "comprado terras aos Pataxós", na paragem de Santa Cruz, freguesia de Furquim. Um ano depois, nenhuma providência havia sido tomada, pelo que temos notícias do capitão do distrito, Sebastião do

\footnotetext{
39 APM, SG, (Secretaria de Governo), cx. 20. doc.4.

40 Há inúmeras menções sobre os ataques indígenas. Ver, por exemplo, APM, CC527, planilha 20233; APM, CC521, planilha 30691; APM, SC97, fot. 47-48; APM, CC546, planilha 21486; 21531; APM, CC547, planilha 21586, 21587; APM, CMM, rolo 8, p. 1130, 1141; APM, SC105, fot. 625, 650; APM, SC111, fot. 296; APM, SC118, fot. 705-708, 716-718; APM, SC150, fot. 224-227, 232, 239-241; 501; 1007; APM, SC203, fot. 860-862, 881-882; APM, SC207, rolo 27, fot. 1921-24; 2028; 2054; APM, SC215, rolo 28, fot. 1429-1430, 1440-45, 1502, 1669, 1672-1673, 1689-1690; APM, SC218, rolo 29, fot. 847; APM, SC219, fot. 957-958; APM, SC229, fot. 407408, 492-493; APM, SC260, fot. 712-713; fot. 730-734; APM, SC276, fot. 1769-1769; APM, SC277, fot. 20322035, 2055-2059; APM, SC294, rolo 39, fot. 777; 790-796, APM, SC326, rolo 43A, fot. 348; APM, SC329, rolo 43A, fot. 1143; 441. BN (Biblioteca Nacional), SM, (Seção de Manuscrito) GAV II-36, 4, 23. PR, AHU, 13080, cx. 179, doc. 36. PR, AHU, 13709, cx. 142, doc. 53.

41 APM, SG10, cx. 35, doc. 5, (1795).

42 APM, SC260, fot. 730-734.

43 APM, SG5, cx. 17, doc.13.
} 
Monte Costa Camargo. Após três anos, a pendenga ainda se arrastava no Senado da Câmara por causa da "compra de terras simuladamente aos índios Pataxós" que além de ilegítima ainda "enganou os índios no preço". ${ }^{44}$

Na região do Rio Pomba, a situação era a mesma. O capitão Silvestre Antônio Vieira, diretor dos índios Cropós e Coroados, denunciava diversos embates entre os colonos e indígenas, em "enganos e negócios ilícitos", "pela falta de observação do cumprimento das ordens régias que têm dado aos mesmos índios motivo de grandes desordens, mortes, causadas pelos portugueses que a força se introduziram nas aldeias e terras dos índios, a título de compra contra a disposição do Diretório Real". Criticava, assim, o Tenente Ângelo Gomes que havia se apossado das terras, sob a alegação de ter pagado vinte quatro mil réis. Denunciava ainda a viúva de João de Almeida e seus filhos de se "apossarem das aldeias dos índios cultivadas e de seus arvoredos frutíferos. ${ }^{45}$

A apropriação de territórios indígenas, por mera ocupação ou compra, especialmente os destinados aos aldeamentos, não calou seus legítimos donos. Nem com toda a opressão, os índios se intimidaram e deixaram de sustentar uma verdadeira resistência, seja pela guerra ou pela quizila judicial. Como bem colocou Regina Celestino, na condição de súditos do rei, os índios aldeados souberam se aproveitar da situação e recorrer ao seus direitos. ${ }^{46} \mathrm{Na}$ Minas Gerais setecentista, essa lógica também prevaleceu, quando índios aldeados acionaram a justiça colonial para se beneficiar.

Repetidas representações foram levadas ao governo da capitania pelos índios Cropós e Coroados também aldeados no Presídio de São João Batista. Em uma das últimas, em 1803, dirigida a Pedro Maria Xavier de Ataíde, dava conta da "necessidade de terras para suas culturas por se acharem distribuídas por sesmarias contra o que sua alteza real expressamente determinou no parágrafo 19, do Diretório de 3 de maio de 1757". Por esta causa, os índios estavam vivendo "dispersos, com fome e obrigados a fazerem-se mais pesados a real fazenda". Solicitavam, então, providências para que fossem "socorridos aqueles desgraçados", posto que havia "intrusos com falsas premissas de títulos que Ihe não competiam", pois que "todos [eram] vassalos do mesmo augusto soberano". ${ }^{47}$

Outros ainda impetraram petições individualmente. Em uma representação à Câmara, um índio croato tentou garantir a posse de suas

\footnotetext{
44 APM, CC549, planilha 10670

45 APM, CC501, planilha 10035

46 ALMEIDA, Maria Regina Celestino de, Os índios aldeados no Rio de Janeiro colonial: Novos súditos cristãos do Império Português. 2001. Tese (Doutorado). Campinas, UNICAMP, 2001, p. 63, 246, 247.

47 APM, SC302, rolo 40, fot. 1517-1519.
} 
terras. Francisco Rodrigues, morador no Presídio de São João Batista, contava que sempre vivera com sua mulher e numerosa família em "manso e pacificamente sem ofender pessoa alguma". Mesmo assim, foi obrigado a interpor uma ação contra colonos posseiros. Antônio Gomes dos Santos e outros "introduziram-se nas suas terras" e queriam Ihe "tomar as ditas chegando a venderem-se algumas". Para intimidá-lo e expulsálo com toda a família, armou-se o tal Antônio, mandando "arrancar a roça de milho", dando-Ihe "muitas pancadas" e "quebrando-lhe o [braço?]". Tudo com a anuência do Diretor dos índios, José Ferreira da Silva, que confessou ter recebido de seu comparsa trinta mil pelas ditas terras. ${ }^{48}$ Esses não foram os únicos a recorrer à justiça colonial para assegurar a propriedade de suas terras. Muitos outros índios "queixosos" "desertaram" do Presídio dos sertões do Rio Xopotó dos Coroatos”, em direção à Vila Rica onde fizeram representação ao governador. ${ }^{49}$ Mesmo assim e a despeito de tanto empenho, nem sempre tiveram sucesso, em função das condições inexoráveis de ocupação territorial.

No governo seguinte, de José Luís de Meneses de Abranches Castelo Branco, Conde de Valadares, outras tantas bandeiras tomaram o mesmo rumo "para a redução do gentio". Estabeleceu, em 1769, duas bandeiras com vinte e cinco homens cada uma. Nomeou, por capitães, os mesmos Antônio Pereira e Antônio Cardoso de Souza. Precavia-se, porém, da avidez dos entrantes, impondo, dessa vez, a condição de que somente usufruiriam do soldo se mostrassem "aumento na conquista". ${ }^{50}$ Tal preocupação procurava garantir um melhor resultado das campanhas para a Coroa, já que nem sempre os interesses régios prevaleciam.

Sob o governo de D. Antônio de Noronha, a situação não mudou a despeito de seu discurso contrário as práticas de seus predecessores. Um relatório apresentado ao Marquês de Pombal, em 1775, avaliava a política dos últimos governos da capitania. Fazendo um balanço sobre os expedientes usados na ocupação do Cuieté, D. Noronha ponderava que as medidas adotadas tinham sido um descalabro. As bandeiras da época do Conde de Valadares, aos seus olhos, consagraram-se como um fiasco. Na sua opinião, as "entradas de mão armada nos matos, assaltando as aldeias indígenas tratadas com toda inumanidade, não reduziram índios alguns à verdadeira crença". O resultado dessa "injusta guerra" não foi outro senão "a avultada despesa da Real Fazenda". Por isso, ponderava que a "religião não se deve introduzir pelas armas", devendo os índios "serem conservados pacificamente em suas aldeias, enquanto não derem causa que Ihe faça guerra" e somente "expulsos"

\footnotetext{
48 APM, CC (Casa dos Contos) 511, planilha 30062.

49 APM, CC525, planilha 20148

50 PR, AHU, 7587, cx. 94, doc. 17.; APM, SC157, fot. 1007-1008.
} 
quando se necessitasse "daquelas terras para a agricultura e para a extração do ouro". Por essa razão, extinguiu as duas companhias de pedestres, criadas pelo Conde de Valadares, destinadas a "rebater os assaltos dos índios", economizando uns tantos tostões ao cofre da Real Fazenda. Para D. Noronha, aquelas milícias eram "inúteis e destinadas a uma conquista reprovada pelo direito das gentes e aos descobertos que nunca devem ser feitos à custa da fazenda" ${ }^{51}$ Mesmo assim, fora justamente sob seu governo que as entradas recrudesceram, demonstrando bem àquelas alturas o descompasso entre as determinações do governador e a disposição dos colonos.

A representação dos oficiais da Câmara de Mariana ao Rei, em 1775, reverberava os ânimos na região. Para eles, apesar dos "bens extraídos da terra a impulsos do laborioso trabalho dos mineiros", aquelas alturas "se contemplava no estado mais deplorável da sua real ruína" com as "atrocidades do gentio que cerca a mesma capitania, destruindo vidas e fazendas". Por isso, muitos moradores abandonavam os sítios "para não experimentarem o efeito de sua crueldade (...) que como feras indômitas se alimentam de carne humana". ${ }^{2}$

Em 1780, sob o patrocínio de D. Rodrigo José de Meneses, desbravou-se todo o leste mineiro até os confins do Cuieté, visando não só a novas jazidas auríferas como também à "cristianização do gentio". Dentro dessa tônica, temos notícias de várias bandeiras que palmilharam o interior. ${ }^{53}$

No albor do século XIX, os colonos ainda apelavam à mesma lengalenga. Recorriam à arenga dos danos aos cofres reais, à indústria e ao comércio, em função dos assaltos do gentio, que levou à "deserção de mais de oitenta fazendas no sertão". Apelavam por uma pronta resposta a "tamanho insulto", às hostilidades de Puris e Botocudos". ${ }^{54}$ Inúmeros clamores dos colonos bateram novamente à porta dos governantes... Em 1806, em Vila Rica, a Mesa da Junta da Administração e Arrecadação da Fazenda Real se reunia, presidida pelo então governador da capitania, Pedro Maria Xavier de Ataíde e Melo para tratar do assunto. Em um discurso inflamado, o governador fez seu pronunciamento aos ministros e deputados presentes: estava "cansado e horrorizado de ouvir o grito dos miseráveis povos que confrontam com a mata geral do rio Doce", no termo de Mariana, "pela carnagem brava e insaciável com que têm sido atacados, mortos e devorados pelos bárbaros antropófagos gentio

51 PR, AHU, 8433, cx. 108, doc. 48. APM, SC221, rolo 28, fot. 908-910

52 PR, AHU, 8417, cx. 108, doc. 75

53 APM, SG05, cx. 16, doc. 15. APM, SG05, cx. 17, doc. 13. PR, AHU, 9167, cx. 118, doc. 97.Ver também APM CC525, planilha 20110. APM, CC506, planilha 10349. APM, SG20, doc. 29. APM, CC524, planilha 20058. APM, SG14, cx. 41, doc. 4.

54 PR, AHU, 11722, cx. 160, doc. 82. 
Botocudo", obrigando-os a "abandonarem suas fazendas de cultura e mineração, depois de já cultivados a preço de seu trabalho" (...) "com excessivo prejuízo dos mesmos, dos reais dízimos, quintos e do aumento da capitania". Manifestando toda sua indignação e admitindo que todas as providências foram "infrutíferas para afastar semelhantes feras", achou por bem "estabelecer três destacamentos". ${ }^{55}$ Com tal expediente, o governador institucionalizava de uma vez por todas a solução militar para lidar com as populações indígenas. ${ }^{56}$ Tal política acenava, ao dobrar o século, para um desfecho pungente e cruento - certamente apropriado aos olhos dos colonos que tanto rogavam por esse epílogo quando, pouco tempo depois, era expedida a Carta Régia, de 13 de maio de 1808, declarando - dessa vez oficialmente - a Guerra contra os Botocudos.

\section{IV - Considerações Finais}

O que se pode perceber é que se, na primeira metade do século, boa parcela de terra tradicionalmente indígena ficou intocável — dados os interesses da política administrativa de manter afastados os colonos das riquezas frente à incapacidade do governo de controlar os extravios e contrabandos - por outro lado, na segunda metade, as entradas incumbiram de combinar a ocupação das terras à redução de diversos grupos indígenas nos aldeamentos - quando não seu pronto extermínio. A esse processo de expropriação, os índios resistiram seja pelo confronto aberto seja pelo acionamento da justiça colonial no intuito de preservar suas terras.

Ao buscar recompor esse cenário, procurei demonstrar que no ritmo dos interesses econômicos, assistimos o delineamento dos contornos da política indigenista de Minas Gerais ao longo de todo o século XVIII refletida, sobremaneira, na solução militar que culminaria na Guerra contra os Botocudos. Com esse caráter, as diversas entradas que romperam os dilatados e inóspitos sertões fizeram senão cumprir esse papel, garantindo a ocupação sistemática do território. Portanto, na Minas que é muitas — tantas ainda por se revelar — não se pode deixar de reconhecer que pouco dela compreenderemos sem levar em conta a Minas dos Cataguases.

55 PR, AHU, 13080, cx. 179, doc. 36

56 Conforme pondera Tarciso Glauco da Silva, essa reunião serviu de base para a criação da Junta da Civilização e Conquista dos Índios e navegação do Rio Doce, com base em cinco objetivos: a guerra ofensiva contra dos botocudos, a formação de corpo militar para cumprir esse objetivo, a divisão da região em seis distritos, o soldo e gratificação por desempenho dos respectivos comandantes e reunião trimestral para avaliação. Junta de civilização e conquista dos índios e navegação do rio doce: fronteira, conflitos e apropriação de espaços (1808-1822. Anais Eletrônicos do XIV Encontro Regional de História. UFJF, 24 a 30 de julho de 2004. 